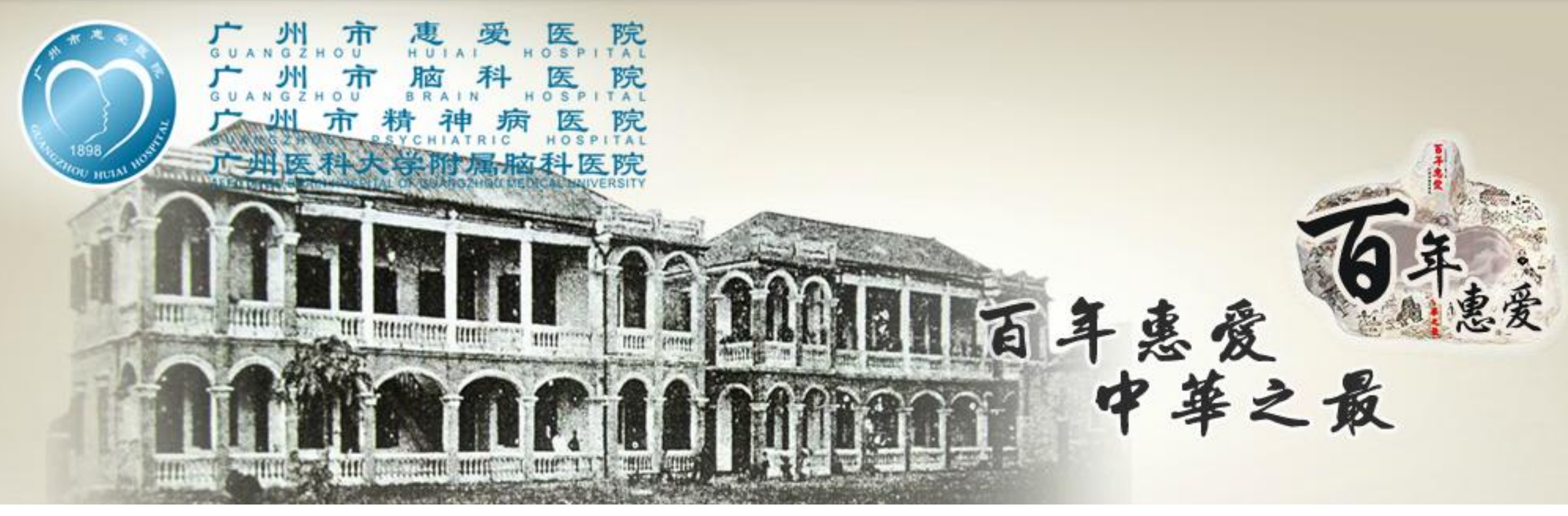

\title{
GRIN2B gene polymorphism in chronic ketamine users
}

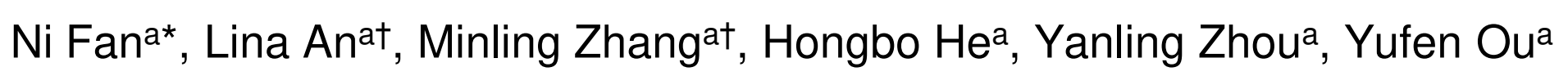

The Affiliated Brain Hospital of Guangzhou Medical University (Guangzhou Huiai Hospital) , 36 Mingxin Road, Liwan District, Guangzhou, Guangdong Province, 510370, China.

\section{Background}

Increasing evidence indicates that the glutamatergic system, particularly the N-methyl-D-aspartate (NMDA) receptor, has played an important role in the rewarding effects of addictive drugs, and genetic polymorphisms in GRIN2B being associated with schizophrenia. Whether GRIN2B gene plays a role in vulnerability in ketamine use is unexplored. The allelic variants of the NMDA Receptor 2B(GRIN2B) in chronic ketamine users were examined, and the association between GRIN2B gene polymorphism and ketamine use conditions were also analyzed.

\section{Resultis}

3.1 Demographics and Clinical data of ketamine users and control subjects (table 1).

3.2 Genotypic distribution of the GRIN2B gene

polymorphisms in ketamine users and control subjects (table 2).

3.3 Allele frequency of SNPs in ketamine users and control subjects (table 3 ).

3.4 Association between drug use characteristics and genotypes of four GRIN2B SNPs in ketamine users.

Ketamine users of genotype TT and CC of rs1806201 had earlier onset of ketamine use than subjects of genotype

TC. The dose of ketamine consumption per day of use was higher in genotype GG of rs7301328 than that in those with $C G$ in ketamine users.

\section{Conelusions}

GRIN2B gene polymorphism may play a role in ketamine abuse.

\section{Acknowledge}

We would like to thank staffs of ward 1 and 2 in Guangzhou Baiyun Voluntary Drug Rehabilitation Hospital for their invaluable assistance. We thank Bin Sun for help on statistical analysis.

\section{Methods}

Four single nucleotide polymorphisms(SNPs) of GRIN2B, rs890, rs1806201, rs7301328 and rs1805502 were examined in 151 male chronic ketamine users and 80 control subjects using a realtime PCR with the $\operatorname{TaqMan}^{\circledR}$ assay system. Clinical symptoms in ketamine users were evaluated with the Positive and Negative Syndrome Scale (PANSS), Beck Depression Inventory (BDI) and the Beck Anxiety Inventory (BAI).

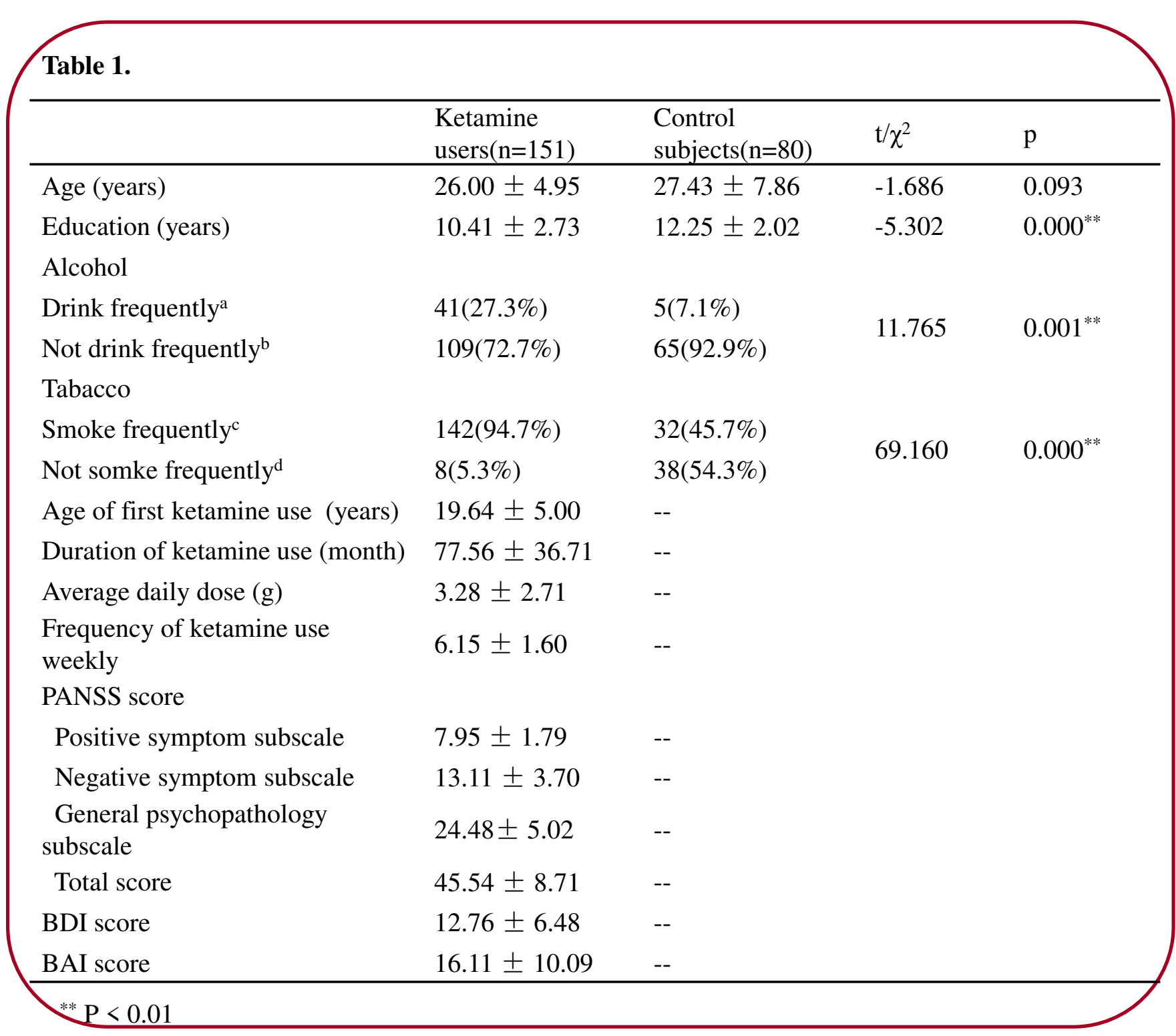

\begin{tabular}{|c|c|c|c|c|c|c|c|c|}
\hline Genotype n(\%) & $\begin{array}{c}\mathrm{KET} \\
(\mathrm{n}=151)\end{array}$ & $\begin{array}{c}\mathrm{CON} \\
(\mathrm{n}=80)\end{array}$ & $\begin{array}{c}\text { Crude } \\
\chi^{2}\end{array}$ & $\mathrm{p}$ & $\begin{array}{c}\text { Crude } \\
\text { OR }(95 \% \mathrm{CI})\end{array}$ & $\begin{array}{c}\text { Adjusted } \\
\chi^{2}\end{array}$ & $\mathrm{p}$ & $\begin{array}{c}\text { Adjusted } \\
\text { OR( } 95 \% \mathrm{CI})\end{array}$ \\
\hline \multicolumn{9}{|l|}{ Rs1806201 } \\
\hline TT & $53(35.1)$ & $22(27.5)$ & 1.077 & 0.241 & $1.426(0.787 \sim 2.582)$ & 2.044 & 0.153 & $1.824(0.800 \sim 4.160)$ \\
\hline ТС & $71(47.0)$ & $34(42.5)$ & 0.431 & 0.512 & $1.201(0.695 \sim 2.074)$ & 1.113 & 0.292 & $1.486(0.712 \sim 3.104)$ \\
\hline $\mathrm{CC}^{1}$ & $27(17.9)$ & $24(30.0)$ & 4.465 & 0.035 & $0.508(0.270 \sim 0.958)$ & 8.167 & $0.004^{*}$ & $0.304(0.134 \sim 0.688)$ \\
\hline
\end{tabular}

\begin{tabular}{|c|c|c|c|c|c|c|c|c|}
\hline SNP ID & & le n (\%) & $\begin{array}{l}\text { Crude } \\
\chi^{2}\end{array}$ & $\mathrm{p}$ & $\begin{array}{c}\text { Crude } \\
\text { OR( }(95 \% \mathrm{CI})\end{array}$ & $\begin{array}{c}\text { Adjusted } \\
\chi^{2}\end{array}$ & $\mathrm{p}$ & $\begin{array}{c}\text { Adjusted } \\
\text { OR(95\%CI) }\end{array}$ \\
\hline Rs1806201 & $\mathrm{T}$ & $\mathrm{C}$ & & & & & & \\
\hline KET & 177(58.6) & $125(41.4)$ & 4.111 & $0.043^{*}$ & 1.489(1.013 2.189) & 6.906 & $0.009^{* *}$ & $2.019(1.196 \sim 3.410)$ \\
\hline $\mathrm{CON}$ & $78(48.7)$ & $82(51.3)$ & & & & & & \\
\hline
\end{tabular}

